\title{
Prawne regulacje w zakresie systemu kolei Unijne i krajowe przepisy dotyczace taboru kolejowego
}

\begin{abstract}
Poniższy artykut jest pierwszym z cyklu pod wspólnym tytułem „Prawne regulacje w zakresie systemu kolei”. Zawiera podstawowe informacje opracowane na podstawie różnego rodzaju dokumentów obowiqzujacych dla taboru kolejowego. Moga być one pomocne w pracy specjalistów zajmujacych się konstrukcja, badaniami oraz certyfikacja taboru kolejowego i jego głównych składników oraz w pracy inżynierów w zakładach produkujacych tabor. Na końcu artykulu umieszczone zostato obszerne zestawienie dokumentów zwiazanych z tematem artykutu.

Artykut zawiera także tzw. linki do stron internetowych, dzięki którym czytelnik może uzyskać dostęp do całych tekstów przytoczonych i omawianych dokumentów. $W$ kolejnych numerach kwartalnika ukazywać się będa kolejne artykuty dotyczqce praktycznego stosowania przepisów dotyczqcych taboru kolejowego.
\end{abstract}

\section{Dyrektywy w zakresie kolejnictwa [1 $\div 4]$ i dokumenty zwiqzane}

Dyrektywa w sprawie interoperacyjności systemu kolei we Wspólnocie [1] zaczyna się preambułą (56 punktów) i składa się z następujących artykułów (wytłuszczoną kursywą wyróżniono te, które dotyczą lub które wymieniaja jednostki notyfikowane (NoBo - Notyfied Body*):

1) Przepisy ogólne, które zawierają następujące części:

- cel i zakres stosowania

- definicje

- ogólna zgodność

- zasadnicze wymagania

2) Techniczne specyfikacje interoperacyjności, na które składają się:

- zawartość TSI

- przyjęcie, przegląd i publikacja TSI

- braki w TSI

- rozszerzenie zakresu stosowania TSI

- odstępstwa

3) Składniki interoperacyjności, z następującym rozdziałami:

- wprowadzenie do obrotu składników interoperacyjności

- zgodność lub przydatność do stosowania

- niezgodność specyfikacji europejskich z zasadniczymi wymaganiami

- procedura dotyczqca deklaracji WE o zgodności lub przydatności do stosowania

- niezgodność składników interoperacyjności z zasadniczymi wymaganiami

4) Podsystemy, opisane w poniższych rozdziałach:

- procedura dopuszczenia do eksploatacji

- swobodny przepływ podsystemów

- zgodność z TSI i przepisami krajowymi

- procedura sporzqdzania deklaracji weryfikacji WE

- niezgodność podsystemów z zasadniczymi wymaganiami

- dopuszczenie istniejących podsystemów do eksploatacji po odnowieniu lub modernizacji

5) Pojazdy, które zawierają następujące części:

- zezwolenie na dopuszczenie pojazdów do eksploatacji

- pierwsze zezwolenie na dopuszczenie do eksploatacji pojazdów zgodnych z TSI

- dodatkowe zezwolenia na dopuszczenie do eksploatacji pojazdów zgodnych z TSI

- pierwsze zezwolenie na dopuszczenie do eksploatacji pojazdów niezgodnych z TSI

- dodatkowe zezwolenia na dopuszczenie do eksploatacji pojazdów niezgodnych z TSI

- zezwolenie na dopuszczenie typów pojazdów do eksploatacji

- klasyfikacja przepisów krajowych 
6) Jednostki notyfikowane

7) Komitet i program pracy z następującym rozdziałami:

- procedura komitetu

- zadania uzupełniające

- program prac

8) Rejestry sieci i pojazdów, opisane w rozdziałach:

- system numerowania pojazdów

- krajowe rejestry pojazdów

- europejski rejestr typów pojazdów dopuszczonych do eksploatacji

- rejestr infrastruktury

9) Przepisy przejściowe; opisują projekt systemów odniesienia

10) Przepisy końcowe, które zawierają następujące części:

- uzasadnienie

- transpozycja

- sprawozdania i informacje

- uchylenie

- wejście w życie

- adresaci.

W latach 2009 - 2013 wprowadzono istotne zmiany dotyczące załączników do dyrektywy [2], [3] i [4].

Opisana dyrektywa była podstawą do opracowania i publikacji szeregu technicznych specyfikacji interoperacyjności, które zawierają wymagania dla odpowiednich podsystemów, wprost lub przez odniesienie do norm europejskich i sporadycznie do kart UIC.

Zgodnie z [3] system kolei podzielony został na podsystemy:

a) strukturalne:

- infrastruktura

- energia

- sterowanie - urządzenia przytorowe

— sterowanie - urządzenia pokładowe

- tabor;

b) eksploatacyjne:

— ruch kolejowy

- utrzymanie

- aplikacje telematyczne dla przewozów pasażerskich i dla przewozów towarowych.

W dalszej części niniejszego artykułu tekst będzie koncentrował się na dwóch podsystemach:

- tabor

- sterowanie - część pokładowa.

Zmienione załączniki to:

Zat. II: Zakres stosowania

Zat. III:Podsystemy

Zat. V: Deklaracja weryfikacji WE podsystemów

Zat. VI: Procedura weryfikacyjna WE dla podsystemów

Zat.VII: Parametry do skontrolowania w celu dopuszczenia do eksploatacji pojazdów niezgodnych z TSI oraz klasyfikacja przepisów krajowych

Link do tekstów ww. dyrektyw (po otwarciu pliku kliknięcie na np. PL otwiera wybrany dokument): http://www.utk.gov.pl/pl/wymagania-wspolnotowe/prawo-wspolnotowe/128, Dyrektywy-

Rozporzadzenia-i-Decyzje.html.

\section{$2 \quad$ Pakiet Technicznych Specyfikacji Interoperacyjności}

Podstawowymi dokumentami zawierającymi wymagania i opisującymi procedury związane z badaniami i weryfikacją podsystemów i składników interoperacyjności są techniczne specyfikacje interoperacyjności wprowadzane w życie decyzjami lub rozporządzeniami Komisji Europejskiej.

Układ tych wszystkich tych dokumentów jest podobny, ich tekst zamieszczony jest w załączniku do wymienionych w pkt. 7 niniejszego artykułu decyzji/rozporządzeń. Wszystkie TSI składają się z następujących głównych punktów: 
- wstęp/wprowadzenie

- definicja podsystemu (i jego funkcje)

- wymagania podstawowe/zasadnicze

- charakterystyka podsystemu (punkt 4: glówny)

- składniki interoperacyjności

- ocena zgodności lub przydatności do stosowania oraz weryfikacja podsystemu

- wdrożenie/wprowadzenie w życie

- załączniki $(\mathrm{A} \doteqdot \ldots)$ - różna liczba załączników w odpowiednich TSI.

Przykładowo charakterystyka podsystemu Tabor (wytłuszczona powyżej) została zredagowana w następującym układzie:

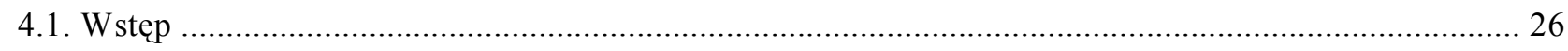

4.2. Specyfikacja funkcjonalna i techniczna podsystemu „TABOR” .......................................................... 27

4.3. Specyfikacja funkcjonalna $i$ techniczna interfejsów ........................................................................ 83

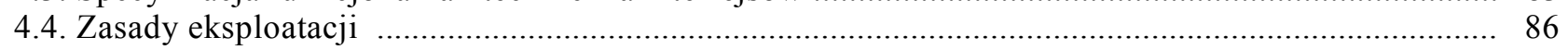

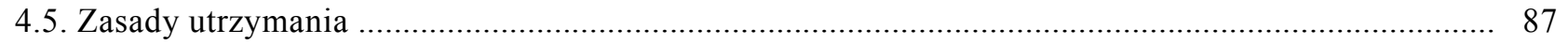

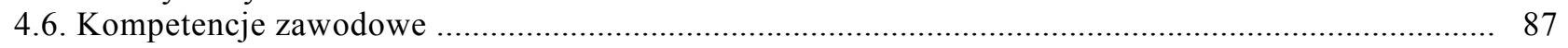

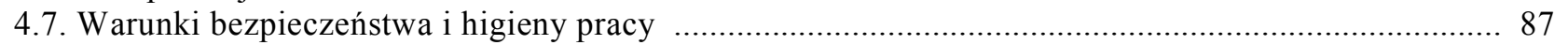

4.8. Europejski rejestr typów pojazdów dopuszczonych do eksploatacji ............................................. 88

Spis treści pkt. 4.2 przedstawia się następująco:

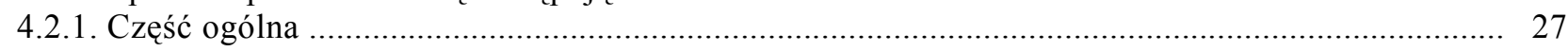

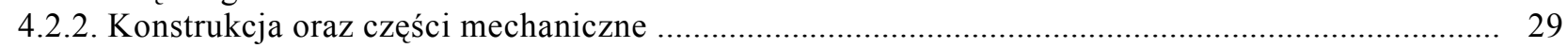

4.2.3. Oddziaływanie między pojazdem szynowym a torem i skrajnią ................................................ 34

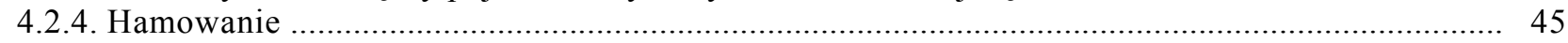

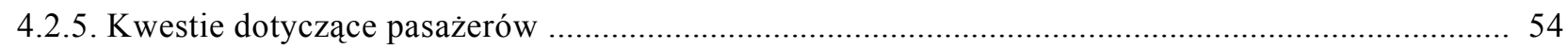

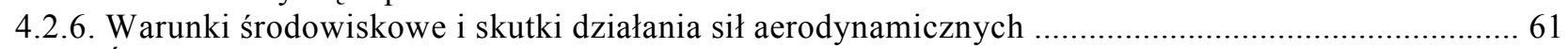

4.2.7. Światła zewnętrzne oraz dźwiękowe i wizualne urządzenia ostrzegawcze..................................... 65

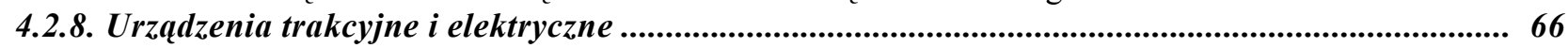

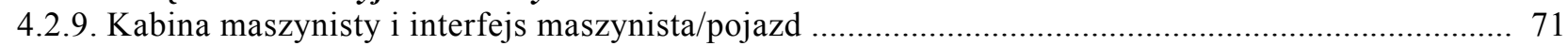

4.2.10. Bezpieczeństwo przeciwpożarowe i ewakuacja .................................................................... 76

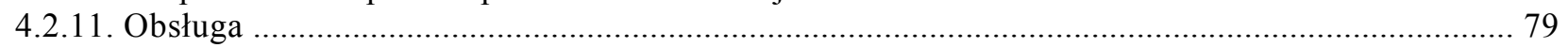

4.2.12. Dokumentacja wymagana do celów eksploatacji i utrzymania ................................................... 80

Dla przykładu, poniżej przedstawiono zawartość podrozdziału 4.2.8.

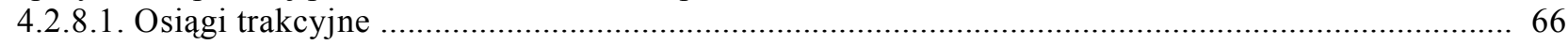

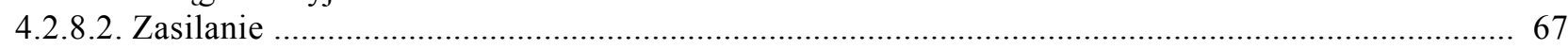

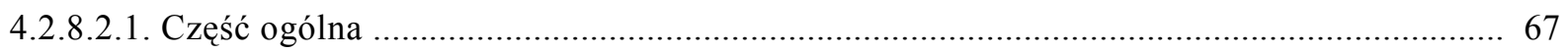

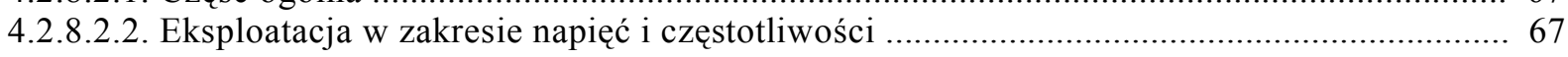

4.2.8.2.3. Hamulec odzyskowy oddający energię do sieci trakcyjnej ................................................ 67

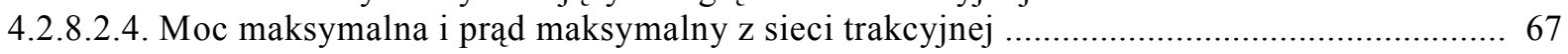

4.2.8.2.5. Prąd maksymalny podczas postoju dla systemów zasilania prądem stałym (DC) ............. 68

4.2.8.2.6. Współczynnik mocy .................................................................................................. 68

4.2.8.2.7. Zakłócenia .... w przypadku systemów zasilania prą̧dem przemiennym (AC) ................... 68

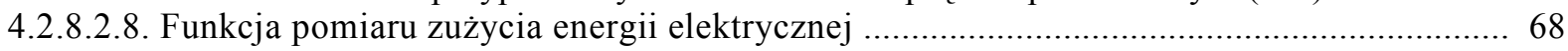

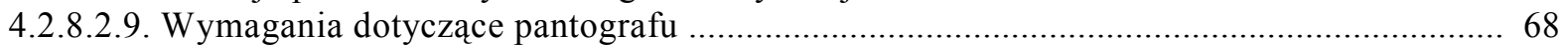

4.2.8.3. Napęd wysokoprężny i inne systemy napędu z silnikami cieplnymi ........................................... 71

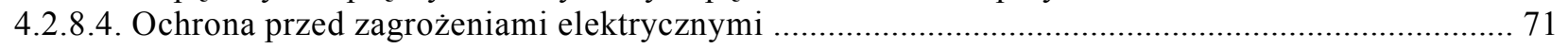

Do TSI - Lok \& pas [5] włączono następujące załączniki:
A. Zderzaki i uktad cięgtowy
B. Punkty podnoszenia na linach i podnoszenia podnośnikiem
C. Przepisy specjalne dotyczqce taboru kolejowego specjalnego przeznaczonego do budowy $i$ utrzymania infrastruktury kolejowej (OTM - maszyn torowych)
D. Licznik energii
E. Wymiary antropometryczne maszynisty
F. Widoczność do przodu
G. Rezerwa
H. Ocena podsystemu ,TABOR”
I. Aspekty, co do których nie jest dostępna specyfikacja techniczna (punkty otwarte)
J. Normy lub dokumenty normatywne przywolane w niniejszej TSI, 
natomiast do TSI - wagony [6] włączono następujące dodatki:

A. Punkty otwarte

B. Procedury szczególne dla dynamiki ruchu

C. Dodatkowe warunki nieobowiazkowe

D. Normy lub dokumenty normatywne przywołane w niniejszej TSI

E. Oznaczenia sygnatowe końca pociagu

F. Ocena przypisana do etapów produkcji

G. Wykaz w petni zatwierdzonych kompozytowych klocków hamulcowych do transportu międzynarodowego.

Należy zwrócić uwagę, że rozdz. 4.2.3.3.1 w [5] został zmieniony w specyfikacji dotyczącej sterowania (załącznik „I” w [11]).

Zakres stosowania pakietu TSI jest zróżnicowany i zależny od rodzaju taboru. W tablicy poniżej, na podstawie [20], zestawiono TSI obowiązujące dla danego rodzaju taboru.

Zestawienie TSI w odniesieniu do rodzaju taboru

Tab. 1

\begin{tabular}{|c|c|c|c|c|c|c|c|c|c|}
\hline Lp. & \multicolumn{2}{|l|}{ Rodzaj taboru } & \multicolumn{7}{|c|}{ TSI (nr wg wykazu w pkt. 7) } \\
\hline 1 & Tabor trakcyjny & \multirow{5}{*}{ 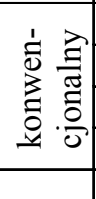 } & 5 & - & 7 & 9 & 8 & 10 & - \\
\hline 2 & Wagony towarowe & & - & 6 & 7 & 9 & - & - & - \\
\hline 3 & Wagony pasażerskie & & 5 & - & 7 & 9 & 8 & - & - \\
\hline 4 & Pojazdy specjalne ${ }^{*}$ ) & & 5 & - & 7 & 9 & - & 10 & - \\
\hline 5 & Koleje dużych prędkos & & - & - & & 9 & 8 & 10 & 12 \\
\hline
\end{tabular}

*) - do obstugi infrastruktury

Opracowane zostały także wytyczne i przewodniki stosowania prawa europejskiego w zakresie kolejnictwa.

\begin{tabular}{|c|c|}
\hline \multicolumn{2}{|r|}{ Europejska Agencja Kolejowa } \\
\hline \multirow{2}{*}{\multicolumn{2}{|c|}{$\begin{array}{l}\text { Przewodnik stosowania technicznych specyfikacji } \\
\text { interoperacyjności (TSI) } \\
\text { zgodnie z mandatem ramowym C(2007)3371 wersja ostateczna } \\
\text { z dnia } 13.07 .2007 \text { r. }\end{array}$}} \\
\hline & \\
\hline Nr ref. w ERA: & ERA/GUI/07-2011/INT \\
\hline Wersja w ERA: & 1.02 \\
\hline Data: & 30 listopada $2012 \mathrm{r}$. \\
\hline
\end{tabular}

Link do tekstów TSI jest następujący:

http://www.utk.gov.pl/pl/wymagania-wspolnotowe/prawo-wspolnotowe/430,Techniczne-

Specyfikacje-dla-Interoperacyjnosci.html, natomiast do tekstów wytycznych i przewodników, jak niżej:

http://www.utk.gov.pl/pl/wymagania-wspolnotowe/wytyczne-i-przewodniki/129,Kluczowedokumenty-pozalegislacyjne.html.

Po otwarciu plików kliknięcie na identyfikator powoduje otwarcie wybranego dokumentu.

\section{Ustawa i rozporzq̨dzenia krajowe ws. kolei i interoperacyjności}

Polskie prawodawstwo w obszarze pojazdów kolejowych zostało podzielone na podstawie [14] na dwa sektory:

A - pojazdy wąskotorowe, do obsługi bocznic i metra: [15], [16] i [17],

B - pojazdy na tor $1435 \mathrm{~mm}$ i na tor szerszy: [18] i [19].

Do pojazdów grupy A odnosi się tryb ,świadectwowy”. Do przeprowadzania koniecznych badań/opiniowania upoważnionych jest aktualnie 14 jednostek wymienionych w zał. nr 3 do [17], wśród nich Instytut Pojazdów Szynowych „TABOR”.

Pojazdy grupy B (zarówno zgodnie jak i niezgodne z TSI) podlegają trybowi „zezwoleniowemu”. 
Weryfikację WE podsystemu (pojazdu) zgodnego z TSI (vide definicja) przeprowadza notyfikowana jednostka (vide definicja), której notyfikacja zawiera odpowiedni zapis w zakresie notyfikacji. W Polsce jest pięć podmiotów notyfikowanych, wśród nich Instytut Pojazdów Szynowych „TABOR” (NB 1940).

Weryfikację podsystemu (pojazdu) niezgodnego z TSI (vide definicja) przeprowadza jednostka uprawniona. Według [19] w Polsce są trzy podmioty, wśród nich Instytut Pojazdów Szynowych „TABOR".

Tryby dopuszczenia do eksploatacji pojazdów kolejowych i typu kolejowego są następujące:

A) pojazdy nie objęte TSI (metro, pojazdy na tor $<1435 \mathrm{~mm}$, do obsługi bocznic)

B) pojazdy objęte TSI

B.1) pojazdy zgodne z TSI

B.1.1) nowe (bez wcześniejszego dopuszczenia w kraju UE)

B.1.2) z wcześniejszym dopuszczeniem w kraju UE

B.2) pojazdy niezgodne $z$ TSI

B.2.1) nowe (bez wcześniejszego dopuszczenia w kraju UE)

B.2.2) z wcześniejszym dopuszczeniem w kraju UE.

Rozporządzenie [21] wprowadza nowe regulacje dotyczące wniosków o „przedłużenie” ważności świadectwa tymczasowego.

Według $\S 2$ ust. 3:

W przypadkach, o których mowa w $\$ 19$ ust. 13, do wniosku o wydanie nowego świadectwa dopuszczenia do eksploatacji typu nie jest wymagane ponowne załaczanie wlaściwych dokumentów, o których mowa w ust. 2 pkt 1,2 i 4.

Według § 19 ust. 13:

Jeżeli próby eksploatacyjne nie moga być wykonane $w$ terminie przewidzianym $w$ programie prób eksploatacyjnych z przyczyn niezależnych od podmiotu ubiegajacego się o wydanie świadectwa dopuszczenia do eksploatacji typu lub ze względu na konieczność przeprowadzenia dodatkowych badań lub ekspertyz, podmiot ten wystepuje z wnioskiem o wydanie nowego świadectwa na czas określony, przewidziany na wykonanie tych prób.

Wystarczające jest wtedy:

3) porozumienie $w$ sprawie wykonania prób eksploatacyjnych, którego wzór określa załacznik nr 2 do rozporzadzenia, wraz z ich programem - dotyczy typów, dla których wymagane jest przeprowadzenie prób eksploatacyjnych.

W innych przypadkach, zgodnie z § 2 ust. 2 pkt. 2), wniosek musi zawierać opinię techniczną jednostki organizacyjnej, o której mowa w poniżej przytoczonym ust. 9 art. 22g Ustawy o transporcie kolejowym [14].

9. Prezes UTK zamieszcza w Biuletynie Informacji Publicznej na stronie podmiotowej Urzędu Transportu Kolejowego wykaz jednostek organizacyjnych uprawnionych do wykonywania badań technicznych koniecznych do uzyskania świadectw dopuszczenia do eksploatacji typu, stwierdzania zgodności z typem oraz wydawania certyfikatów zgodności typu i certyfikatów zgodności z typem wraz ze wskazaniem zakresu ich uprawnień.

Jednostka uprawniona musi uzyskać certyfikat akredytacji na podstawie ustawy [22] o systemie oceny zgodności w zakresie odpowiadającym prowadzonej działalności.

W ustawie [14] w art. 4. znajduje się, ważny dla jednostek upoważnionych w okresie przejściowym, zapis:

Jednostki, które przed dniem wejścia w życie niniejszej ustawy, zostały upoważnione do przeprowadzania badań koniecznych do uzyskania świadectw dopuszczenia do eksploatacji typu, na podstawie przepisów wydanych na podstawie art. 23 ust. 7 pkt 1 lit. b ustawy, o której mowa w art. 1 , $w$ brzmieniu dotychczasowym, moga wykonywać badania $w$ zakresie określonym $w$ tych przepisach, a także wydawać certyfikaty zgodności typu i certyfikaty zgodności z typem dla typów urzqdzeń, budowli i pojazdów kolejowych, do badania których sq upoważnione, nie dlużej niż do dnia 31 grudnia $2015 \mathrm{r}$.

\section{Definicje}

Dla łatwiejszego prezentowania treści odnośnych przepisów można przytoczyć za [1], [13], [14], [17] i [19] następujące definicje: 
Interoperacyjność systemu kolei: zdolność systemu kolei do zapewnienia bezpiecznego i nieprzerwanego ruchu pociągów, spełniającego warunki techniczne, ruchowe, eksploatacyjne i prawne, których zachowanie zapewnia dotrzymanie zasadniczych wymagań dotyczących interoperacyjności systemu kolei i umożliwia efektywne poruszanie się po transeuropejskiej sieci kolejowej;

Jednostki notyfikowane: organy odpowiedzialne za ocenę zgodności lub przydatności do stosowania składników interoperacyjności oraz za prowadzenie procedur weryfikacji WE podsystemów.

Jednostki uprawnione: organy odpowiedzialne za przeprowadzenie badań niezbędnych do dopuszczenia do eksploatacji pojazdów kolejowych niezgodnych z TSI.

Jednostki upoważnione: jednostki organizacyjne upoważnione do przeprowadzania badań koniecznych do uzyskania świadectw dopuszczenia do eksploatacji typu.

Uwaga: W rozporzqdzeniu [17] zmieniono nazwę: jednostka wyznaczona $\longrightarrow$ jednostka uprawniona.

Pojazd zgodny z TSI: pojazd, który jest zgodny ze wszystkimi istotnymi TSI obowiązującymi w momencie dopuszczenia do eksploatacji, pod warunkiem, że znaczna część zasadniczych wymagań została określona $\mathrm{w}$ tych TSI i że odpowiednia TSI dotycząca taboru weszła $\mathrm{w}$ życie i ma zastosowanie - art. 22 ust. 1 dyrektywy w sprawie interoperacyjności.

Pojazd niezgodny $\mathbf{z}$ TSI: pojazd, które nie jest zgodny ze wszystkimi stosownymi TSI obowiązującymi $\mathrm{w}$ dniu dopuszczenia tego pojazdu do eksploatacji, w tym pojazdy objęte odstępstwami, lub gdy znaczna część zasadniczych wymagań nie została ujęta w jednej lub kilku TSI - art. 24 ust. 1 dyrektywy w sprawie interoperacyjności.

Składnik interoperacyjności: podstawowe składniki, grupy składników, podzespoły lub zespoły, które są włączone lub które mają być włączone do podsystemu, od którego pośrednio lub bezpośrednio zależy interoperacyjność systemu kolei; składnikiem interoperacyjności jest również oprogramowanie.

Certyfikat weryfikacji WE podsystemu: dokument wydany przez notyfikowaną jednostkę certyfikującą potwierdzający, że podsystem jest zgodny z zasadniczymi wymaganiami dotyczącymi interoperacyjności systemu kolei.

Certyfikat WE zgodności lub przydatności do stosowania składnika interoperacyjności: dokument wydany przez notyfikowaną jednostkę certyfikującą potwierdzający, że składnik interoperacyjności jest zgodny z zasadniczymi wymaganiami dotyczącymi interoperacyjności systemu kolei lub potwierdzający, że składnik interoperacyjności jest przydatny do stosowania.

Link do krajowych aktów prawnych (kliknięcie po otwarciu pliku otwiera wybrany dokument): http://www.utk.gov.pl/pl/akty-prawne/227,Akty-Prawne-obowiazujace-w-Urzedzie-TransportuKolejowego.html

\section{$5 \quad$ Projekty unijnych aktów prawnych}

Tryb opracowywania i wprowadzania w życie nowych lub znowelizowanych przepisów w zakresie kolei europejskich charakteryzuje się dużą dynamika, dlatego warto śledzić nie tylko zachodzące zmiany, lecz także zapowiedzi zmian. Jedna z tych zapowiedzi jest przedstawiono poniżej.

\begin{tabular}{|c|c|c|c|}
\hline \multicolumn{4}{|c|}{ INTEROPERABILITY UNIT } \\
\hline \multicolumn{4}{|c|}{ EUROPEAN UNION RAIL SYSTEM } \\
\hline \multicolumn{4}{|c|}{ SUBSYSTEM ROLLING STOCK } \\
\hline \multicolumn{4}{|c|}{ TSI "LOCOMOTIVES AND PASSENGER RST" } \\
\hline Reference & IU-LOC_PAS_TSI & Document type & Technlcal Speclflcatlon for Interoperabllity \\
\hline Version & 2.0 & Status & Final draft \\
\hline Date & $11 / 12 / / 2012$ & & \\
\hline
\end{tabular}


Przykładowo, w tłumaczeniu roboczym autora, podano tekst punktów wybranych ze względu na odniesienie do polskiej specyfiki:

7.1.1.4 Zastosowanie do pojazdów projektowanych wytacznie do eksploatacji w systemie $1520 \mathrm{~mm}$.

(1) Zastosowanie tych TSI do pojazdów, które maja być eksploatowane wytacznie w systemie 1520 mm nie jest obowiqzkowe podczas okresu przejściowego kończacego się po 6 latach po dacie zastosowania tych TSI.

7.1.1.5 Tymczasowe środki dla wymagań bezpieczeństwa pożarowego

(1) Podczas okresu przejściowego kończqcego sie po 3 latach po dacie zastosowania tych TSI jest dozwolone, jako alternatywa do wymagań materiatów wyspecyfikowanych w pkt. 4.2.10.2.1 obecnych TSI, stosowanie weryfikacji zgodności dla wymagań bezpieczeństwa pożarowego materiatów wedlug przepisów krajowych (stosujac odpowiednie kategorie operacyjne) spośród jednego z poniższych zestawów norm:

(2) norma brytyjska BS6853, GM/RT2130 wydanie 3

(3) norma francuska NF F 16-101:1988 i NF F 16-102/1992

(4) norma niemiecka DIN 5510-2:2009 zawierajaca pomiary toksyczności

(5) norma wtoska UNI CEI 11170-1:2005 and UNI CEI 11170-3:2005

(6) norma polska PN-K-02511:2000 and PN-K-02502:1992

(7) norma hiszpańska DT-PCI/5A.

Przewiduje się także rozszerzenie liczby składników interoperacyjności o pozycję:

5.3.13 Fotel maszynisty.

Link (po otwarciu pliku kliknięcie na np.PL otwiera wybrany dokument):

http://www.utk.gov.pl/pl/wymagania-wspolnotowe/prawo-wspolnotowe/775, Projekty-Aktow-

Prawnych.html.

\section{Podsumowanie}

Zaplanowany przez Unię Europejska proces intensyfikowania rozwoju transportu kolejowego powoduje tworzenie nowego prawa, zawierającego wymagania prowadzenia sformalizowanych procedur związanych z szeroko rozumianym bezpieczeństwem tego rodzaju transportu. Działania czysto techniczne, które były dotąd podstawową częścią pracy inżynierów branży kolejowej, następują w drugiej kolejności w ich pracy. Fakt ten powinien przekonywać do konieczności sprawnego poruszania się w coraz większym gąszczu przepisów, choćby po to, by dokonywać ich odpowiedniej selekcji i działać efektywnie, bez popełnienia kroków zbędnych lub fałszywych.

Przedstawiony artykuł jest próbą takiego działania. Jest wynikiem analiz dokumentów prawnych, ich aktualnego stanu i historii zmian, a na jej podstawie prezentuje podstawową wiedzę i jej źródła na temat przepisów dotyczących zagadnienia określonego tytułem referatu.

Należy zwrócić uwagę na obszerność aktualnych aktów prawnych i ich wzajemne powiązanie. Powinno to być dla zainteresowanych podmiotów zachętą do bieżącego śledzenia i właściwego interpretowania tych przepisów, a także podpowiedzią dla stowarzyszeń działających w branży kolejowej o potrzebie organizowania szkoleń i warsztatów praktycznych na temat europejskiego i krajowego stanu prawnego w dziedzinie systemu kolei.

W kolejnych numerach kwartalnika ukażą się kolejne artykuły:

- Akredytacja, autoryzacja i notyfikacja ośrodków certyfikujących i laboratoriów badawczych

- Ocena zgodności podsystemu „TABOR” i jego składników interoperacyjności

- Ocena zgodności podsystemu „Sterowanie - urządzenia pokładowe” i jego składników interoperacyjności

- Ocena bezpieczeństwa podsystemu „TABOR” w zakresie wyceny i oceny ryzyka.

\section{Obowiqzujace dokumenty:}

[1] Dyrektywa Parlamentu Europejskiego i Rady 2008/57/WE z dnia 17 czerwca 2008 r. w sprawie interoperacyjności systemu kolei we Wspólnocie

[2] Dyrektywa Komisji 2009/131/WE, z dnia 16 października 2009 r. zmieniajqca załacznik VII do dyrektywy Parlamentu Europejskiego i Rady 2008/57/WE w sprawie interoperacyjności systemu kolei we Wspólnocie

[3] Dyrektywa Komisji 2011/18/UE z dnia 1 marca 2011 r. zmieniajqca załaczniki II, V, VI do dyrektywy Parlamentu Europejskiego i Rady 2008/57/WE w sprawie interoperacyjności systemu kolei we Wspólnocie 
[4] Dyrektywa Komisji 2013/9/UE z dnia 11 marca 2013 r. zmieniajqca załacznik III do dyrektywy Parlamentu Europejskiego i Rady 2008/57/WE w sprawie interoperacyjności systemu kolei we Wspólnocie

[5] Decyzja Komisji $z \quad$ dnia $26 \quad$ kwietnia 2011 r. $\quad w$ sprawie technicznej specyfikacji interoperacyjności dla podsystemu „Tabor - lokomotywy $i$ tabor pasażerski” $w$ europejskim systemie kolei konwencjonalnych (2011/291/UE)

[6] Rozporzqdzenie Komisji (UE) nr 321/2013 z dnia 13 marca 2013 r. dotyczace technicznej specyfikacji interoperacyjności odnoszacej się do podsystemu „Tabor - wagony towarowe” systemu kolei w Unii Europejskiej i uchylajace decyzję 2006/861/WE

[7] Decyzja Komisji z dnia 4 kwietnia 2011 r. dotyczqca technicznej specyfikacji interoperacyjności odnoszacej się do podsystemu „,Tabor kolejowy - hatas” transeuropejskiego systemu kolei konwencjonalnych (2011/229/UE)

[8] Decyzja Komisji z dnia 21 grudnia 2007 r. dotyczqca technicznej specyfikacji interoperacyjności w zakresie aspektu "Osoby o ograniczonej możliwości poruszania się" transeuropejskiego systemu kolei konwencjonalnych $i$ transeuropejskiego systemu kolei dużych prędkości (2008/164/WE)

[9] Decyzja Komisji z dnia 20 grudnia 2007 r. dotyczqca technicznej specyfikacji interoperacyjności $w$ zakresie aspektu "Bezpieczeństwo $w$ tunelach kolejowych" transeuropejskiego systemu kolei konwencjonalnych i transeuropejskiego systemu kolei dużych prędkości (2008/163/WE)

[10] Decyzja Komisji z dnia 6 listopada 2012 r. zmieniajaca decyzje 2012/88/UE w sprawie technicznej specyfikacji interoperacyjności $w$ zakresie podsystemów „Sterowanie” transeuropejskiego systemu kolei (2012/696/UE)

[11] Decyzja Komisji z dnia 25 stycznia 2012 r. w sprawie technicznej specyfikacji interoperacyjności w zakresie podsystemów ,,Sterowanie” transeuropejskiego systemu kolei (2012/88/UE)

[12] Decyzja Komisji z dnia 21 lutego 2008 r. dotyczqca specyfikacji technicznej interoperacyjności podsystemu „,TABOR” transeuropejskiego systemu kolei dużych prędkości (2008/232/WE)

[13] Część 1 dokumentu referencyjnego przewidzianego $w$ art. 27 dyrektywy $w$ sprawie interoperacyjności kolei. Wytyczne dotyczqce stosowania.

[14] Ustawa z dnia 28 marca 2003 r. o transporcie kolejowym (Dz. U. $2003 \mathrm{nr} 86$ poz. 789) z późniejszymi zmianami: z dnia 12.07.2013 (Dz. U. poz. 1033), z dnia 30.08.2013 (Dz. U. poz. 1152) oraz z dnia 24.04.2014 (Dz. U. poz. 644)

[15] Rozporzqdzenie Ministra Transportu, Budownictwa i Gospodarki Morskiej z dnia 7 sierpnia 2012 r. w sprawie wykazu typów budowli przeznaczonych do prowadzenia ruchu kolejowego, typów urzadzeń przeznaczonych do prowadzenia ruchu kolejowego oraz typów pojazdów kolejowych, na które sq wydawane świadectwa dopuszczenia do eksploatacji typu (Dz. U. poz. 911)

[16] Rozporzadzenie Ministra Transportu, Budownictwa i Gospodarki Morskiej z dnia 7 sierpnia 2012 r. w sprawie zakresu badań koniecznych do uzyskania świadectwa dopuszczenia do eksploatacji typu budowli przeznaczonej do prowadzenia ruchu kolejowego, świadectwa dopuszczenia do eksploatacji typu urzqdzenia przeznaczonego do prowadzenia ruchu kolejowego oraz świadectwa dopuszczenia do eksploatacji typu pojazdu kolejowego (Dz. U. poz. 918)

[17] Rozporzqdzenie Ministra Transportu, Budownictwa i Gospodarki Morskiej z dnia 10 sierpnia 2012 r. w sprawie świadectw dopuszczenia do eksploatacji typu (Dz. U. poz. 919)

[18] Rozporzqdzenie Ministra Transportu, Budownictwa i Gospodarki Morskiej z dnia 27 grudnia 2012 r. w sprawie wykazu właściwych krajowych specyfikacji technicznych i dokumentów normalizacyjnych, których zastosowanie umożliwia spetnienie zasadniczych wymagań dotyczqcych interoperacyjności systemu kolei (Dz. U. 2013 poz. 43)

[19] Rozporzqdzenie Ministra Transportu, Budownictwa i Gospodarki Morskiej z dnia 6 listopada 2013 r. w sprawie interoperacyjności kolei (Dz. U. 2013 poz. 1297)

[20] Rozporzqdzenie Ministra Transportu, Budownictwa i Gospodarki Morskiej z dnia 6 listopada 2013 r. w sprawie interoperacyjności systemu kolei (Dz. U. 2012 poz. 492)

[21] Rozporzadzenie Ministra Infrastruktury $i$ Rozwoju z dnia 13 maja 2014 r. w sprawie dopuszczenia do eksploatacji określonych rodzajów budowli, urzadzeń i pojazdów kolejowych (Dz. U. 2014 poz. 720)

[22] Ustawa o systemie oceny zgodności z dnia 30 sierpnia 2002 r. (Dz. U. $2002 \mathrm{nr} 166$ poz. 1360) z późniejszymi zmianami: z dnia 13.07.2010 (Dz. U. nr 138 poz. 935), z dnia 15.04.2011 (Dz. U. nr 201 poz. 586), z dnia 13.06.2013 (Dz. U. poz. 898) 